\title{
A decrease of the rabbit's physiologic IOP after the application of specific amino acids and double combination of antiglaucomatics mixture
}

\author{
Olah Z, Veselovsky J \\ Department of Ophthalmology, Comenius University, Bratislava, Slovakia. olahz@stonline.sk
}

\begin{abstract}
Purpose: To compare the effect of amino acids mixtures to a double combination of antiglaucomatics on the physiologic intraocular pressure (IOP) in rabbits.

Methods: Experimental evaluations were performed on 5 female rabbits of the New Zealand White species.

Results: 1) After instillation of $10 \% \mathrm{~L}$-arginine. $\mathrm{HCl}$ in the double combination of antiglaucomatics: a) $0.5 \%$ Timolol with $0.005 \%$ Xalatan mixture, the biphasic IOP decrease was measured. The mean decrease in 24 hours was -2.9 torr; b) $2 \%$ Trusopt with $0.005 \%$ Xalatane mixture in 24 hours, the biphasic decrease of the IOP was measured. The mean decrease in 24 hours was -4.2 torr; c) Fixed combination COSOPT the mean IOP value decrease was -1.8 torr. 2) The IOP decrease achieved during 24 hours by instillation of the amino acid $10 \%$ L-taurine. $\mathrm{HCl}$ and the double combination of antiglaucomatics: $0.5 \%$ Timolol with $0.005 \%$ Xalatane mixture was in average -2.8 torr. The pupilar diameter was not changed.

Conclusions: We assume that after the interaction of the selected amino acids $10 \% \mathrm{~L}$-arginin or $10 \% \mathrm{~L}$-taurin with the double combination of antiglaucomatics (Trusopt and Xalatan, COSOPT or Timoptol and Xalatan) a new substance was formed. The effect of this substance is not separate or additive but acts as a newly formed substance. In vivo, it is only a weak interaction with the free amino acids of the conjunctival sac and the antiglaucomatics. The amino acids interacted in vitro with the double combination of antiglaucomatics resulting in a new „bio-antiglaucomatic" better penetrating into the target area. This new substance was responsible for a more significant decrease and regulation IOP after the mixture application compared to the antiglaucomatics alone (Fig. 1, Ref. 23). Full Text in PDF www.elis.sk.

Key words: IOP influence in experiment, rabbits IOP after mixture, amino acids arginine, taurine, double combination of antiglaucomatics.
\end{abstract}

The clinical experience still has to prove that antiglaucomatic drugs are instilled in combinations or together to reduce the IOP in case of an insufficient effec. However, recent literary data (Keates, 1979; Haas and Drance, 1980; Steinert et al, 1981; Kass, 1983; Freedman et al, 1983; Ruko et al, 1984; Alm et al, 1985; Urtti and Kyyrönnen, 1989; Sharir et al, 1994; Alm et al, 1995) doesn`t explain the mechanism of this synergy. Based on these facts and experimental study we focused on this problem.

To penetrate the tissue barriers, the drugs instilled into the conjunctival sac should integrate with the free amino acids present in tears. According to our assumption, the therapeutic effect of the drugs ("prodrugs") instilled into the conjunctival sac is in mutual interaction with their binding on the free amino acids in tears. In this interaction process with relevant amino acid during activation in conjunctival sac a new substance (metabolite) originate. This new substance can penetrate into the target region and after release, the components can be metabolized only as unbounded

Department of Ophthalmology, Comenius University, Bratislava, Slovakia Address for correspondence: Z. Olah, MD, DSc, Department of Ophthalmology, Comenius University, Bratislava, Ruzinovska 7, SK-826 06 Bratislava, Slovakia. into the biologically active form. We suppose that this mode of action - bioactivation resulting to formation of the new substance - bioregulator (acting as ,bio-antiglaucomatic”) is responsible for the therapeutic effect of antiglaucomatics.

These problems are not sufficiently explained by available data. Therefore, we focused on the evaluation of these interactions between amino acids and antiglaucomatics and the influence on the intraocular pressure (IOP). Our series of experimental evaluations was pointing out the fact that for the function of antiglaucomatic its interaction with amino acids is essential (Oláh and Veselovský, 2003; Veselovský et al, 1998a; 1998b; 2002; 2003a; 2003b; 2004). An addition of amino acid (which is the natural part of the tears in the conjunctival sac) to the antiglaucomatic influences the improvement of antiglaucomatics penetration into the intraocular structures. Our results with the Ninhydrine agent (Veselovský et al, 1998a) for the amino acid presence (compared the colour differences with the standard amino acids) proved the assumption that in the mixture of single amino acid in vitro with the single antiglaucomatic a new metabolite is generated - the ready substance able to influence the IOP.

In this study, we modelled a condition that should occur after the specific amino acids with two antiglaucomatic were applied into the conjunctival sac. Using our observations, we would like 
to stress the importance of this interaction of aminoacids with antiglaucomatic drugs from the view of their effect on IOP decrease and minimization of their side effects.

\section{Material and methods}

The experimental evaluations were performed on 5 female rabbits of the New Zealand White species with physiological IOP levels. All rabbits were treated in the Slovak centre of the agriculture research - breeding of rabbits, Nitra, No. reg.: SK-Ch-29004. The rabbits were kept under a constant temperature $+20{ }^{\circ} \mathrm{C}$ and under the standard light regimen. All rabbits were fed by the standard feeding mixture and water was supplied on demand.

The presented experimental study was focused to examine the pharmacokinetic effect of mixtures with some free amino acids present in the conjunctival sac:

1) $10 \% \mathrm{~L}$-arginine. $\mathrm{HCl}$ in the double-combination of antiglaucomatic drugs: a) $0.5 \% \beta$-blocker Timolol maleas $(0.5 \%$ Timoptol, fy. Zentiva) $+0.005 \%$ prostaglandin analogue $\mathrm{F}_{2 \alpha}$ Latanoprost (0.005 \% Xalatan, fy. Pharmacia\&Upjohn); b) $2 \%$ carbonic anhydrase inhibitor Dorsolamid.HCl (2\% Trusopt, fy. MSD $)+0.005 \%$ Xalatan; c) fixed combination COSOPT $(0.5 \%$ Timolol maleas $+2 \%$ Dorsolamid. $\mathrm{HCl}$ ) or

2) $10 \% \mathrm{~L}$-Taurine. $\mathrm{HCl}$ in the double-combination of antiglaucomatic drugs $0.5 \%$ Timoptol $+0.005 \%$ Xalatan on the IOP physiological values in rabbits.

At 8.00 am, we instilled two drops of solution into the left conjunctival sac of the experimental rabbits. The solution for these experiments was prepared to achieve (after recalculation of concentrations) the same result: $10 \%$ amino acid in antiglaucomatic with baseline concentration and $\mathrm{pH}$. The right eye of the same rabbit was used as the control. To secure an absence of the possible residuum from the previously applied solutions, we kept one week interval between the application of the respective substances.

The IOP values and pupillary diameter were measured at the time of instillation, in the 15th, 30th, 60th, 120th, 180th, 240th min and 24 hours after the instillation. Both eyes before each IOP measurement were anesthesized by one drop of $0.5 \%$ Mesocain. The IOP values were measured using the Schiötz's tonometer (with $5.5 \mathrm{~g}$ load). All values were verified using the Maklakov's applanation tonometer and applanation tonometer „TONO-PEN XL" produced by Medtronic SOLAN, USA.

All recorded were statistically evaluated using the Student's t-test.

\section{Results}

Before the application, we tested all above mentioned mixtures of amino acids and antiglaucomatics in vitro with the Ninhydrine agent for the amino acid presence and the colour differences were compared to the standard amino acid. The coloration of the mixture specific for peptides confirmed the interaction on the amino acid with antiglaucomatic and proved the creation of a new physiologically active substance. After the application of the substance created by the interaction, no changes in the pupil-

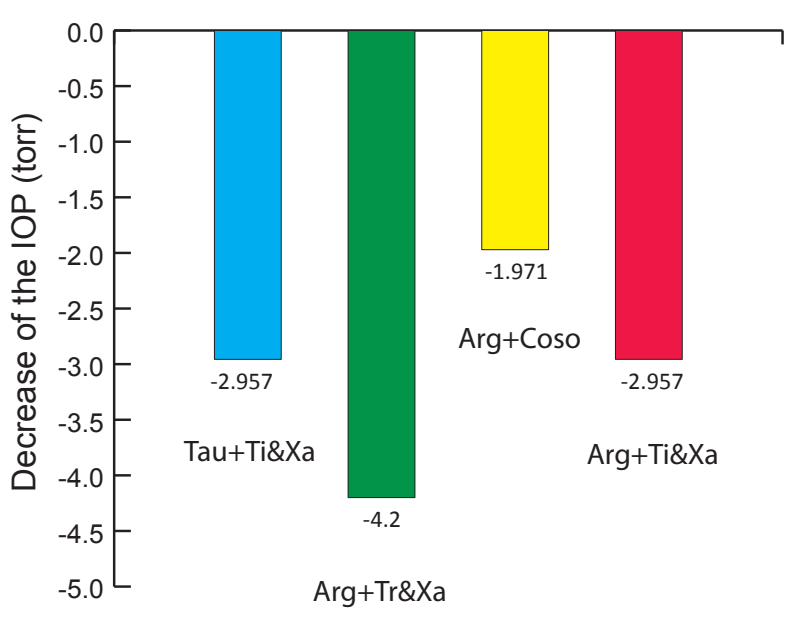

Fig. 1. Mean value of decrease of the rabbit's IOP after interaction of some amino acids in double combination of antiglaucomatics. Arg+Ti\&Xa $=10 \%$ L-arginin. HCl $+0.5 \%$ Timoptol \& $0.005 \%$ Xalatan; Arg+Tr\&Xa $=10 \%$ L-arginin. $\mathrm{HCl}+2 \%$ Trusopt \& $0.005 \%$ Xalatan; Arg + Coso $=10 \%$ L-arginin. HCl + Cosopt (0.5 \% Timoptol \& $2 \%$ Dorsolamid); Tau+Ti\&Xa $=10 \%$ L-Taurin.HCl $+0.5 \%$ Timoptol \& $0.005 \%$ Xalatan.

lary diameter on the eye used for experiment and on the control eye were observed.

Interaction of some amino acids with 2 antiglaucomatics (Fig. 1)

a) After instillation of the $10 \% \mathrm{~L}$-arginin. $\mathrm{HCl}$ in the double combination of antiglaucomatics $0.5 \%$ Timoptol with $0.005 \%$ Xalatan mixture, the biphasic IOP decrease was measured. The maximal effect of this mixture was observed in the 30th min (decrease -4.1 torr) and in the 120th min and 180th min (decrease -3.4 torr). The mean decrease of the physiological IOP in rabbits in 24 hours was -2.9 torr,

b) The instillation of the $10 \% \mathrm{~L}$-arginine. $\mathrm{HCl}$ in the double combination of antiglaucomatics $2 \%$ Trusopt with $0.005 \%$ Xalatane mixture in 24 hours, the biphasic decrease of the IOP was observed. The maximal effect of this mixture was in $30 \mathrm{~min}$ (decrease of -5.1 torr). The evidence of the effect was present also after 24 hours (decrease in -2.5 torr). The mean value of the IOP decrease was -4.2 torr,

c) After instillation of the $10 \% \mathrm{~L}$-arginine. $\mathrm{HCl}$ and the fixed double combination of antiglaucomatic COSOPT (timolol+ dorsolamid) mixture, the IOP showed a significant decrease. The IOP decrease between 15 to 60 min was linear (for -1.8 and -2.2 torr). Compared to the control eye, the major IOP decrease was measured in the 240th $\min (-2.2$ torr; $-17.98 \%)$. In 24 hours after the instillation, the IOP did not reach the control values, the IOP decrease was -0.4 torr $(-2.12 \%)$. The mean IOP decrease compared to the control eye was -1.8 torr $(-9.64 \%)$.

The topic application of the amino acid $10 \% \mathrm{~L}$-taurine. $\mathrm{HCl}$ and antiglacomatics $0.5 \%$ Timoptol with $0.005 \%$ Xalatan mixture in all measured times (except measurement in the 60th min) had a clearly beneficial effect with significantly decreased IOP values $(p<0.10)$. The maximal decrease $(-4.3$ torr) was in the 180 th min. This mixture achieved the IOP decrease by -2.9 torr in average. 
From the 30th min after the application, the control eye showed IOP increase for +2.7 torr in average.

\section{Discussion}

Considering the presence of the biological functional barriers, the penetration of pharmaceuticals after the application into the conjunctival sac and their bioavailability in the eyeball`s tissue structures is the essential question (Hart, 1992). Penetration into the tissue structures of the eye is not managed by diffusion only, but also solubility, chemical reactions of substances and other factors play a role. Verkman et al (2008) stressed also an important physiological role of aquapurins in the transport mechanism of various substances. We assumed that specifically selected amino acid interacted in vitro with the selected antiglaucomatic replacing the in vivo interaction in the conjunctival sac, where according to Kahán (1982), 11 amino acid were present.

Our series of experimental evaluations was pointing out the fact that for the function of antiglaucomatic its interaction with amino acids were essential (Veselovský et al, 1998a, 1998b, 2002, 2003, 2004). In our published experimental studies (Oláh and Veselovský, 2007 and others) we have found that already in vitro interaction of amino acids with antiglaucomatic resulted in new metabolite. The aminoacids and antiglaucomatic mixture caused the formation of a new metabolite in interaction and this new substance alone or in combination significantly decreased IOP in healthy rabbits without influencing the pupillary sphincter. The addition of amino acids (which is the natural part of the tears in the conjunctival sac) to the antiglaucomatic influenced the improvement of antiglaucomatic penetration into the intraocular structures with a possible increase of their effec. Based on our observations, we can state that not every antiglaucomatic decreases the IOP values with particular amino acid significantly and for the same duration.

In case when a prepared mixture is applied (thus already completed metabolite), the interaction between antiglaucomatic and amino acid is much more thorough and vigorous. This metabolite instilled into the rabbits ' conjunctival sac influenced the IOP more intensively already in physiological conditions. This fact was confirmed by the current results with the mixtures of $10 \%$ amino acids lysine, arginine, glycine or taurine in $0.5 \%$ Timolol (Oláh and Veselovský, 2007). At the same time, we observed that the effect of in vitro prepared ready bio-antiglaucomatic was several times higher than its individual components.

Our performed experimental observations partially contributed to the clarify of the mode of action of a double combination of antiglaucomatics in the process of decrease and regulation of the IOP. In the interaction process with relevant amino acid, a new substance originated - a bioregulator (,,bio-antiglaucomatic”). This new substance can penetrate into the target region and the components can be metabolized only as unbounded into the biologically active form. We suppose that this mode of action (bioactivation) - resulting into the new substance - bioregulator acting as „,bioantiglaucomatic" is responsible for the effect of antiglaucomatics. This mechanism probably controls the decrease of production or increase of outflow of the aqueous humor through the uveoscleral system resulting in a decreased IOP level.

Based on our observations, we can state that not each amino acid with a double combination of antiglaucomatics decreased the IOP values significantly and for the same duration. The showed effect on IOP based on interaction of some amino acid mixture with the double combination of antiglaucomatics was specific and its efficacy together with a duration changed according the type of amino acid. Our observations proved the clearly defined interaction specificity of the individual amino acid with the double combination of antiglaucomatics in vivo and also in vitro conditions, as was stressed by Veselovský et al (2004) and Oláh et al (2005).

\section{Conclusion}

The IOP decrease achieved by various antiglaucomatics with the same amino acid was different in significance and duration. The showed effect on IOP based on the interaction of amino acid mixture with the double combination of antiglaucomatics was specific and the efficacy together with a duration changed according the type of amino acid. The addition of amino acids in vitro (which are the natural part of the tears in the conjunctival sac) to the double combination of antiglaucomatics influenced the improvement of antiglaucomatic penetration into the intraocular structures with an increase of their effect. The intensive and longlasting effect of the „bioantiglaucomatic" we see in the selective specificity based on the fact that the specific antiglaucomatic can interact with the specific amino acid only.

\section{References}

1. Alm A, Widencard I, Kjellgren D, Soderstrom M, Fristrom B, Heijl A, Stjerschantz J. Latanoprost administered once daily causes a maintened reduction of intraocular pressure in glaucoma patients treated concomitently with timolol. Brit J Ophthal 1955; 79: 12-16.

2. Freedman KA, Klein JW, Crosson CE. Beta-cyclodextrins enhace bio-availability of pilocarpine. Current Eye Res 1993; 12 (7): 641-647.

3. Hass I, Drance SM. Comparison between pilocarpine and timolol on diurnal pressures in open-angle glaucoma. Arch Ophthal 1980; 98: 480-481.

4. Hart WM. Intraocular Pressure. 248-267. In: Hart WM Jr (Ed). Adler's Physiology of the Eye. StLouis-Baltimore-Boston-Chicago-LondonPhiladelphia-Sydney-Toronto: Mosby, 1992, 888 p.

5. Kahán IL. Zur Biochemie des Auges. Akadémiai kiadó, Budapest, 1982, $113 \mathrm{p}$.

6. Kass MK. Efficacy of combining timolol with other antiglaucoma medications. Surv Ophthal 1983; 274-279.

7. Keates ED. Evaluation of timolol maleate combination therapy in chronic open-angle glaucoma. Amer J Ophthal 1979; 88: 565-571.

8. Nielsen NV. The ocular hypotensive effect of timolol in long-term treatment of glaucoma. Acta Ophthal 1982; 60: 961-966.

9. Oláh Z, Veselovský J. Vplyv amínokyseliny L-arginínu.HCl na aktivitu Trusoptu v komorovom moku. Transacta Ophthal Slov 2003; 3 (1): 5-8.

10. Oláh Z, Veselovský J, Gressnerová $S$, Veselá A. The rabbit's IOP after instillation of antiglaucomatic COSOPT and amino acid L-arginine. $\mathrm{HCl}$ mixture in the conjunctival sac. Čes Slov Oftal 2005; 61 (1): 3-12. 
365-368

11. Oláh Z, Veselovský J. Rabbits intraocular pressure after instilation of Timolol and aminoacids lysine, arginine, glycine or taurine mixture. Bratisl Lek Listy 2007; 107: 283-286.

12. Sharir M, Zimmerman TJ, Del Negro RG, Ball SF, Kooner KS. A comparison of the eficacy of various metipranolol-pilocarpine combinations in patients with ocular hypertension and primary open-angle glaucoma. J Ocul Pharmacol 1994; 10 (2): 411-420.

13. Steinert RF, Thomas JV, Boger WP III. Long-term drift and continued efficacy after multiyear timolol therapy. Arch Ophthal 1981; 99: 100-103.

14. Rulo AH, Greve EL, Hoyng PF. Additive effect of latanoprost, a prostaglandin F2 $\alpha$ analoge, and timolol in patients with elevated intraocular pressure. Brit J Ophthal 1994; 78: 899-902.

15. Urtti R, Kyyrönnen K. Ophthalmic epinephrine, phenylephrine, and pilocarpine affect the systemic absorbtion of ocularly applied timolol. J Ocul Pharmacol 1989; 5 (2): 127-132.

16. Verkman AS. Role of aquaporin water channels in eye function. Review. Exp Eye Res 2003; 76: 137-143.

17. Veselovský J, Oláh Z, Veselovská Z, Veselá A. Mechanism of pilocarpine effect in tissue structures of the eye anterior segment from the point of its interaction with free amino acids. Čs Oftal 1998a; 54 (1): 10-17.

18. Veselovský J, Oláh Z, Veselovská Z, Veselá A. Bioaktivita zmesi pilokarpínu s lyzínom na pupilu a vnútroočný tlak očí králikov. Čs Oftal 1998b; 54 (6): 353-361.
19. Veselovský J, Oláh Z, Veselá A, Gressnerová S. Fyziologický význam interakcie timololu s vol'nými aminokyselinami v štruktúrach oka. Čes Slov Oftal 2002; 58 (3): 143-148.

20. Veselovský J, Oláh Z. Elevated activity of the antiglaucomatic $2 \%$ Trusopt in humor aqueous combined with amino acid L-arginin.HCl. 297304. In: Bulla J, Kováčik J, Zeman MV (Eds). Celoslovenský seminár z fyziológie živočíchov (Zborník z vedeckého seminára s medzinárodnou účastou). Nitra: Slov. pol'nohosp. Univ., 2003a, 363 p.

21. Veselovský J, Oláh Z, Veselá A, Gressnerová S. Zmes timoptolu s L-argininom.HCl: regulátor vnútroočného tlaku u králikov. Čes Slov Oftal 2003b; 59 (5): 295-302.

22. Veselovský J, Oláh Z, Veselá A, Gressnerová S. Porovnanie efektivity zmesi aminokyseliny $10 \%$ L-arginínu. $\mathrm{HCl}$ v $0,5 \%$ Timoptole a v $2 \%$ Trusopte a jednotlivých zložiek na VOT v experimente u králikov. Čes Slov Oftal 2004a; 60 (3): 163-170.

23. Veselovský J, Oláh Z, Veselá A, Gressnerová S. Reaction of the Physiological IOP in Rabbits after Application of the Latanoprost (Xalatan) and Amino Acid L-arginine.HCl Mixture. Čes Slov Oftal 2004b; 60 (5): $319-327$.

Received November 1, 2011. Accepted January 23, 2013. 